\title{
Using community development theory to improve student engagement in online discussion: a case study
}

\author{
Elisabeth Skinner* \\ Department of Natural and Social Sciences, University of Gloucestershire, Cheltenham, UK
}

(Received 8 May 2008; final version received 18 March 2009)

\begin{abstract}
Online discussion can be designed to develop the skills and confidence of students as well as providing an opportunity for constructing knowledge. If students decide not to participate or join too late, they put their own development and the quality of the learning community at risk. This article reflects on a first term undergraduate experience of a series of online discussion activities which failed to inspire timely and constructive participation.

The case study identifies flaws in the design of the discussion, constructed using Salmon's five-stage model, and shows how easy it is to miss the point when designing an online activity. Participation is a pre-requisite for developing community so this article discusses how professional community development workers identify and overcome barriers to participation strengthening engagement in a community by stimulating personal and emotional interests. In the case study, discussion topics failed to strike a personal chord with many students. This has implications for designing activities that engage each student's interest from the outset so that participation in the discussion becomes a truly creative experience.
\end{abstract}

Keywords: online discussion; Salmon's five-stage model; learning communities; student engagement

\section{Introduction}

Learning often takes place in a social setting where participation in shared activities creates a community of practice (Wenger 1998). Online discussion has developed as an activity where people interact to construct knowledge, negotiate meaning and thereby create a community of learners (e.g. Salmon 2000). Active participation in either face-to-face or online discussion is a choice for students, and sometimes students choose not to join in. Potentially, students who decide not to contribute lose opportunities for learning.

So how can teachers design engaging online discussions? This article responds to a question posed by Downing et al. in ALT-J (September 2007) and inspired by Bourne et al. (1997): "what works in terms of encouraging early engagement with the asynchronous use of the bulletin/discussion board?" (Downing et al. 2007, 203). In Downing's case study the tutor created a supportive environment fostering trust, but his central point is that success depended on a formative assessment activity designed to encourage social interaction. Each student introduced another student to the group in online space, creating a sense of belonging and a comfortable medium for making

*Email eskinner@glos.ac.uk 
friends. The experience reviewed below shows how easy it is to make mistakes in designing discussion; it examines a specific example where students shed light on poor motivation for participation.

This example involved 25 new undergraduates studying management in three disciplines including community development. Community engagement theory, derived from practice in encouraging people to participate in local communities, offers suggestions that help teachers improve student engagement in online communities. This article applies these ideas to enhance the experiences of learners through online discussion strengthened by genuine personal meaning.

\section{The value of participation and community development theory}

Encouraged by a commitment to the value of online discussion as an essential mechanism for creating a community of learners, teachers may feel aggrieved when students fail to join. "I had always expected that as soon as the virtual classroom door swung open at the start of the semester, my students would come pouring through, but this has not always been the case for all students" (Bender 2003, 47).

Participation in a learning community depends first on a student being present and secondly on the student interacting with others by making a contribution to discussion. People are justified in observing online discussion without interaction as a prelude to taking part. Reporting on a workshop facilitated by Jacquie MacDonald and involving Etienne Wenger who developed the concept of communities of practice (CoPs), it was suggested that "lurking is a form of cognitive apprenticeship which can be seen as legitimate peripheral participation in discussion-oriented CoPs" (MacDonald et al. 2003 , 4). However, simply being present in a group setting is not enough if people are to develop individual skills and confidence and contribute to the welfare of a community.

Community development workers stress that capacity building or personal development does not occur before but through participation (Warburton 1998, 33). Therefore people who lack the skills or confidence for either being present or interacting are excluded from the very activities that might help them to develop skills or confidence for community engagement. The aim is to encourage people to step over the threshold and then to help them join in.

There are many reasons, based on shortcomings or fears, which prevent people from participating in a community. Community development researchers find that people might lack awareness, time, confidence, education, skills or motivation for contributing (Dalziel, Hewitt, and Evans 2007; Fraser 2005). Dalziel, Hewitt and Evans, in a report for the UK's Department of Communities and Local Government, argue that people can be afraid of the unknown, of using the wrong words, of alienating their peer group, of being patronised (Dalziel, Hewitt, and Evans 2007). What is more, meeting places can be "inhospitable places where people felt intimidated" (Dalziel, Hewitt, and Evans 2007, 17). Similarly Skidmore, Bound and Lownsborough (2006), researching participation for the Joseph Rowntree Foundation, found that communities are often dominated by enthusiastic, well-connected and unapproachable insiders whose position is reinforced by the trust of those in local government. Potential participants find this off-putting.

All these factors are relevant to the range of meeting spaces, from face-to-face to virtual, that some students will find daunting. They may be overcome by fears or perceived inadequacies in comparison with others in the class, while teachers can be 
seduced by strong students to reinforce the barrier between insiders and outsiders. Inclusion in a learning community is as vital to the individual in class as it is in a local community: "feeling included in a group is an important factor for encouraging the true potential for learning to take place" (Bender 2003, 3).

A note of caution is appropriate. The imposition of values, such as 'participation is good for you', runs counter to the principle of empowerment. MacDonald et al. report that this point was made at the workshop on communities of practice: "enticing lurkers into active participation ... feels a bit like the 'father knows best' school of homogenization" (2003, 6). Similarly, Ferreday and Hodgson $(2008,647)$ reflect on the debate that peels away the utopian image of participation to reveal its dark side; "participative processes can be experienced as tyrannical when participation is demanded by course designs, tutors and ultimately by participants in an unreflective and normative way". However, community development researcher, Malcolm Moseley $(2003,90)$ suggests that the failure to involve people in collective or community action, is the "squandering of a considerable resource" of human and social capital. These uncomfortable tensions create an unexpected challenge for the teacher designing online discussion. Nevertheless, while recognising that some students will not be willing or able to join a learning community for a variety of personal reasons, the teacher has a responsibility to design activities that are engaging and provide an enjoyable learning experience for as many students as possible. In particular, the intention is to develop confidence for participation where it does not already exist. People who remain outside the community risk reinforcing their disadvantage, missing out on opportunities for developing skills and knowledge.

\section{Background to the case study}

The question for the research study was to find out which barriers prevented students from enjoying the potential benefits of participation in the online community for 'Management at Work', a first level module taught at the University of Gloucestershire.

The case study research in 2006/07 built on work undertaken in previous years. In 2004/05 a study of participation in online discussion for the module 'Town and Country Planning' found that the failure of some students to engage severely damaged the experience of community for those keen to participate. Participating students are upset by the absence of others (demonstrating the dark side of participation highlighted by Ferreday and Hodgson, 2008).

A significant proportion of students (36\% in Town and Country Planning) were not sufficiently trusting to share their lack of knowledge with their group while for some students, the activities taught them directly about the failure of trust. These students felt let down when other group members failed to participate, leading in one instance to an angry accusation that other students should not 'judge someone they don't even know'. (Skinner 2007, 386)

The research in 2004/05 compared the troubled experience of assessed online discussion in 'Town and Country Planning' with an experience that the students found more comfortable in the module 'Management at Work'.

Further research examining the management module in 2005/06 suggested that additional support would strengthen students' capacity to participate: "students may grow in confidence through online discussion but if they lack sufficient capacity to participate, then they are clearly in difficulty from the outset" (Skinner and Derounian 
2008 , 59). Therefore the aim of the research in 2006/07 was to test improvements to student support for 'Management at Work' to enhance student engagement in the assessed online discussion.

The module is taken by first year undergraduates studying heritage, environmental or community management. Later in the year the same students use WebCT for two other online discussion assignments. The first debates a controversial planning application while the second is a collaborative essay about community development principles, so it is important to introduce the students to online discussion early in their course.

Five discussion tasks in 'Management at Work' were originally designed using Salmon's five-stage model (Salmon 2000), introducing students gradually to knowledge construction using the WebCT discussion tool. The activities were expected to extend classroom discussion, help the students get acquainted and develop cooperation based on shared interests. Students taking the same subject would build a group identity and apply general management ideas to their discipline.

To encourage students to engage the discussions were assessed, carrying $50 \%$ of the marks for the module. The first task involved an account of personal experiences of management (Stage 1: Access and Motivation). Next, the students suggested their goals for the module and discussed motivation as a management tool (Stage 2: Online Socialisation). Thirdly, they shared subject-related resources and discussed current issues in their field (Stage Three: Information Exchange) and fourthly they applied management ideas from their reading to management roles in relevant professions (Stage 4: Knowledge Construction). They concluded with task five, reflecting on their performance and evaluating the discussion experience (Stage 5: Development). The teacher provided written generic feedback after tasks one and two and individual feedback after tasks three to five to build students' confidence and suggest improvements. Students gained credit for thoughtful responses, for their ability to stimulate discussion and for their support of other students.

Salmon's model provided an appropriate framework for introducing new students to online discussion. Moule (2007) argues that the model is too narrow in its focus on knowledge construction in a group setting but where this is the defined purpose of online discussion it provides a useful starting point. The experience of using the model supports Salmon's response to Moule in which she stresses its adaptability (Salmon 2007). The model proved a valuable guide early in the teacher's experience of designing online discussion but, with practice, confidence to question and adapt the model and use alternative approaches develops. In the event, it has still proved difficult to design each discussion topic so that it provides an engaging experience for every student. When it was discovered during the 2006/07 run of the module that a high proportion of students were entering discussions after published deadlines, it became important to find out why. As Tisha Bender, an online teaching consultant working in America, suggests,

even though the online environment is an asynchronous one, we want to avoid having stragglers who pull the discussion in a backward direction by their late participation; and ideally we want everyone in the class to be involved in the same discussion at approximately the same time. (Bender 2003, 47)

\section{Methodology: investigating participation}

The 25 new students studying 'Management at Work' were grouped online according to their subject (heritage, environment or community) with 7, 15 and 3 students in the 
three groups. Each activity was given a published deadline to help students manage their time over an eight-week period. The fifth deadline was the formal submission date with extensions required if the deadline was not met.

As a consequence of research in the previous year, additional support was introduced to strengthen students' skills and confidence before the start of the discussion and to make sure that they were equipped with the tools they needed for joining in. MacDonald notes that teachers can help by providing accessible support, face-to-face, by e-mail or telephone, to suit individual students' needs $(2006,29)$. An audit of students' attitudes and confidence in online communication and writing skills was conducted in the first week followed by two hands-on workshops using computers in the second and third weeks (Table 1). Another survey in week four showed where attitudes, skills or levels of confidence had changed. The aim of the audit was to identify students requiring more focused support during and after the workshops. All students completing the audits agreed that the findings could be analysed as part of the research project.

Coates $(2006,69)$ argues that 'time on task' "is too blunt a measure to capture the educational experience" but this research was not designed to examine the quality of student engagement in online discussion. It arises from a concern that quality depends on students being present in the discussion and ready to contribute. The timing of each student's first participation in each activity was therefore monitored and registered by

Table 1. Timetable of events.

\begin{tabular}{|c|c|c|c|c|}
\hline & Task & Salmon's five stages & Support activity & Research activity \\
\hline Week 1 & & & & $\begin{array}{l}\text { First skills audit } \\
\text { (detailed) }\end{array}$ \\
\hline Week 2 & & & $\begin{array}{l}\text { First hands-on } \\
\text { WebCT } \\
\text { workshop }\end{array}$ & \\
\hline Week 3 & $\begin{array}{l}\text { Task One: } \\
\text { Introductions }\end{array}$ & $\begin{array}{l}\text { Stage One: Access } \\
\text { and motivation }\end{array}$ & $\begin{array}{l}\text { Second hands-on } \\
\text { WebCT } \\
\text { workshop }\end{array}$ & \\
\hline Week 4 & $\begin{array}{l}\text { Task Two: } \\
\text { Performance } \\
\text { Targets }\end{array}$ & $\begin{array}{l}\text { Stage Two: Online } \\
\text { socialization }\end{array}$ & & $\begin{array}{l}\text { Second skills audit } \\
\text { (light touch) }\end{array}$ \\
\hline \multicolumn{5}{|l|}{ Week 5} \\
\hline Week 6 & $\begin{array}{l}\text { Task Three: } \\
\text { Information } \\
\text { Exchange }\end{array}$ & $\begin{array}{l}\text { Stage Three: } \\
\text { Information } \\
\text { exchange }\end{array}$ & & \\
\hline Week 7 & $\begin{array}{l}\text { Task Four: } \\
\text { Management } \\
\text { Issues }\end{array}$ & $\begin{array}{l}\text { Stage Four: } \\
\text { Knowledge } \\
\text { construction }\end{array}$ & & \\
\hline \multicolumn{5}{|l|}{ Week 8} \\
\hline Week 9 & $\begin{array}{l}\text { Task Five: } \\
\text { Performance } \\
\text { Review }\end{array}$ & $\begin{array}{l}\text { Stage Five: } \\
\text { Development }\end{array}$ & & $\begin{array}{l}\text { Students' } \\
\text { reflection on } \\
\text { motivation in } \\
\text { Task Five }\end{array}$ \\
\hline \multicolumn{5}{|l|}{ Week 10} \\
\hline Week 11 & & & & Interviews \\
\hline Week 12 & & & & Interviews \\
\hline
\end{tabular}


the teacher. Analysis separated students who engaged in the activity by the advertised deadline from those who entered discussion in the week after the deadline and others who contributed more than seven days late.

This data was linked to individual students' attitudes gathered from the skills audit, from students' written evaluation of the experience and from seven interviews conducted following completion of the module. The skills audit in the first week and observation of students' reactions to workshops in the second and third weeks provided insights into their approaches to online discussion before they engaged. In particular it identified students who lacked skills and confidence for whom online working might prove difficult.

Students' evaluations of the assessed online discussion provided further evidence for their attitudes to participation. In task five, students were asked to reflect on their motivation for contributing to the five activities, building on an earlier discussion of motivation as a management tool. They were also encouraged to offer a critique of the assignment showing how it could be improved.

This situation creates problems for the researcher who is also designer, teacher and assessor. First there is a danger that students' reflections are compromised by a lack of anonymity and by the need to perform for assessment. However, there is no evidence that students were cautious in their comments for fear of displeasing their marker; they appeared sufficiently trusting by task five to be critical of the activities and expressed feelings openly to their group and the assessor.

Secondly, a researcher closely involved in the design, delivery and assessment of discussions might influence outcomes by advising students on how to respond and will be unable to review the data with complete objectivity. On the other hand, the teacher as researcher is doing what all teachers should do - critically evaluating their teaching, learning and assessment activities by encouraging students to express their views.

Thirdly, it is not acceptable to use students' work for a purpose of which they are not aware and without their consent. Garrison and Anderson (2003) argue that there is no need to obtain students' permission to observe discussions since observation is the teachers' function. In this case, students knew that their contributions to task five would be used to evaluate the assignment and identify improvements, and afterwards they were presented with a report and response to their commentary.

Once the module was completed, seven students (28\%) were interviewed to probe their feelings about the experience and their perceptions of learning. The seven students were volunteers and so possibly better motivated with a positive attitude to online discussion. However, four of the seven started with considerable anxiety regarding the activity while their levels of motivation, attitudes to learning and timing of their contributions varied considerably. Two of the seven were never late while one was a little late, one was extremely late throughout and the remaining three were occasionally very late. These students gave written consent to their views being quoted below.

\section{Results and discussion}

The results of this investigation suggest that the work on building skills and confidence before the activities was insufficient to facilitate participation. Three quarters of the students met the deadline for task one because it took place during the second hands-on workshop in class but only $16 \%$ of the 25 students met all five deadlines, 
Table 2. Meeting deadlines.

\begin{tabular}{lccc}
\hline Deadline & \% on time & $\% 1$ to 7 days late & $\%$ over 7 days late \\
\hline 1 & 76 & 12 & 12 \\
2 & 24 & 36 & 40 \\
3 & 24 & 44 & 32 \\
4 & 24 & 12 & 64 \\
5 & 76 & 12 & 12 \\
\hline
\end{tabular}

while most students struggled to participate on time. As many as $76 \%$ of the students failed to meet the deadlines for tasks two, three and four, although only $24 \%$ were late for task five, but even this was a significant problem because it was the formal submission date. It was more of an issue that as many as $64 \%$ were more than a week late engaging in the fourth discussion (Table 2).

Students at interview expressed significant fears or feelings of inadequacy at the outset, especially related to online discussion (Table 3).

Salmon's five-stage model for e-moderating begins with 'access and motivation'. "Strong motivation is a prime factor at this stage, when participants have to tackle the technical problems" (Salmon 2000, 27). Indeed, six students in the research study $(25 \%)$ used the skills audit in week one to identify their lack of technical skills and confidence. Following the two hands-on workshops at computers in weeks two and three, a second audit showed that anxiety had been significantly reduced. Five of the six students were sufficiently well-motivated to overcome their fears and participate effectively in the discussion activity.

Since the remaining $75 \%$ of the class claimed, in both skills audits, to be confident with online networking, it is fair to assume that any failure to participate effectively was not caused by inadequate ICT skills and difficulty in accessing the task. Indeed the review of individual performances shows that all but one of the students who would struggle to meet deadlines felt that they had the technical skills and confidence for participation at the outset.

Table 3. Examples of feelings at the start of the activity.

A At the start I was just a bit overwhelmed by the whole university thing. ... Some people
are quite confident. I'm not very confident.
At the beginning I had absolutely no idea what we were doing or what [WebCT] was
for, or the relevance of it. I just thought it was another kind of tool the university was
using that didn't really matter; you could just kind of skip over it and forget about it.
.. To be fair, before I started University I wasn't that PC literate. I have had to learn
everything again really. On a personal level that's probably got something to do with
it [delayed engagement].
At the start I was absolutely against [online discussion] 100\%. I couldn't have hated it
more - the whole concept of doing it. Really hated the idea of it. In actual fact I was
thinking of dropping [the subject].
At the beginning, I was having a lot of problems with self-confidence and trying to get
to grips with the computer system. I'd given up rather easily, ran away, or whatever.
But through determination, through just perseverance, I got to know it really well and
ended up enjoying it.


Salmon continues, "it is also motivating at the start to make very clear to participants the value of CMC [computer-mediated communication], its links to and integration with the rest of the course, its role in assessed components (tests and assignments) and the amount of time they should allocate to its use" (Salmon 2000, 27). Similarly Ellis et al. (2007) provide research evidence to show that students must understand the purpose of both face-to-face and online discussions linked to the learning outcomes of their course. Clearly it is important to explain the purpose of online discussion and the benefits of joining a learning community but this may not provide the "good reason" that Salmon suggests students need for participating. Even where explanations are given students find them difficult to grasp at this early stage perhaps because there is so much happening in their first weeks at university (see Table 3 ). In the community development field, Dalziel, Hewitt and Evans found that the rewards of participation "are somewhat intangible and it is likely that people will be unaware of these benefits until they take part" $(2007,26)$. So students may have a theoretical awareness of benefits if these are explained, but without a successful experience, motivation to take part might still be lacking. The trick is to design discussion activities that clarify the relevance of the discussion to "what the students are supposed to be learning" (Ellis et al. 2007, 95).

In her study of principles for enhancing student engagement, Krause warns of the failure to motivate students: "In cases where students lack motivation and connectedness, the potential is high for inertia to deteriorate into despondency and disengagement from the university community" (Krause 2007, 5). Indeed, it was the absence of motivation that created the disappointing levels of participation in the research case study. This was clearly expressed in the interviews and the students' reflections on motivation in task five. Half of the students stressed their lack of motivation in evaluating the assignment. In fact $25 \%$ of the students admitted a lack of motivation in the first audit but this was not immediately picked up. Oddly, even though the module title was 'Management at Work', the students had little interest in management itself. Many had not chosen the module because it was compulsory. It was thought that all students would have experience of management in school and through voluntary or paid work so the first online task included asking students to share these experiences:

Introduce your previous experience of management. Everyone has experiences of management - at school, at work, at home, in the community or in social groups. Tell your group about an experience of either good or poor management.

But one student in his interview said he expected all management courses to be "off target". Another admitted: "I don't like management; it's boring. You start the course off with that and then it's always going to be an uphill struggle". He offered advice: "if you take it the other way, you get students all excited and then just guide them into the stuff they think is boring!"

'The other way' might come from the students' enthusiasm for their own subject. For some students this was the key: for example, "when I found out I was in a small group who were all doing heritage, and that many of the tasks involved applying management principles to heritage, my motivation for this assignment improved greatly". One student who demonstrated poor levels of confidence from the start noted that she was "into energy at the moment" and was keen to discuss the energy debate. In some cases, the students expressed their genuine emotional engagement in their subject: "I have a passion about heritage and all things like history, that's what I really enjoy. ... If you're really interested in something and you are passionate about 
something you could talk all day". The activity clearly failed to strike a chord with students at the beginning. As one student said, "if it doesn't flick my switch, I'm just going to do the absolute necessity and that's really it".

The activity failed to motivate students because it asked the wrong questions and this kept barriers to participation in place. In some cases, students were motivated, not by the activity, but by a determination to succeed, driven by their conception of learning as personal development (Entwistle 2003). One student explained that the purpose of learning was "to broaden your horizons", while another said "my goals are quite clear; I know what I want to achieve". This determination enabled some students, especially the more mature starting with a lack of ICT confidence, to conquer their fears and participate effectively. Other students saw learning as the acquisition of knowledge about their subject so a discussion about their own uninspiring experiences of management failed to meet their expectations.

\section{Learning as a personal experience}

The research demonstrated the diversity of the student group, their different conceptions of learning and the variety of their skills, needs, interests and expectations. The interviews provided an opportunity for getting to know individuals and discovering the deeply personal nature of learning experiences (e.g. Table 3).

There is considerable emphasis on personalised learning in pedagogic literature. Krause (2007), for example, notes that it is "a priority to get to know your students, their needs, aspirations and motivations". Learning designers often refer to the importance of recognising students' needs and attitudes to learning. Authors "rethinking pedagogy for a digital age" (Beetham and Sharpe 2007) emphasise this point:

Designers need to examine their learning designs from the perspective of their impact on learning, that is, placing themselves in the 'students' shoes' and thus examining their learning designs from the student perspective. (Oliver et al. 2007, 67)

The individual and personal self remains at the centre of every learning experience, despite appreciation that learning is a social or community activity. Deci and Ryan (1985) provide a basis in psychology by emphasising the power of the self to determine behaviour. Self-determination or motivation from within is central to an individual's development.

Intrinsic motivation is in evidence whenever students' natural curiosity and interest energize their learning. When the educational environment provides optimal challenges, rich sources of stimulation, and a context of autonomy, this motivational wellspring of learning is likely to flourish. (Deci and Ryan 1985, 245)

The extrinsic motivation of assessment is not enough to encourage students to participate in a timely and effective manner in an online discussion. As Bender suggests, there are many reasons why students fail to engage with an online discussion on time, and although some are to do with access and technical barriers, others are linked with a lack of excitement. Bender's purpose is to show how to get the online discussion "off to a sizzling start" (Bender 2003, 47). Barnett and Coate are more measured: "the curriculum needs to be designed to accord students time and space to come into a positive relationship with their experiences, [or] the necessary commitment and engagement just will not occur" (Barnett and Coate 2004, 139). 
Community development work concentrates on igniting people's interest in participating: "the willingness to be involved may need sparking" (Henderson and Thomas 2002 , 106). Personal interest and need is the key that unlocks each individual's motivation to participate in community activity. Dalziel, Hewitt and Evans (2007, 21-3) found that people will get involved if it helps them achieve a personal goal, meet an emotional need or address strong feelings. Community development involves reaching out into the space where individuals are at ease and using personal contact to draw people in (Skidmore, Bound, and Lownsborough 2006, 50; Gilchrist 2004, 20-1; Moseley 2003, 97). Henderson and Thomas argue that people may appear apathetic but this is a false impression; community development workers help them express "the vigour, initiative and skills which in fact exist in them" $(2002,106)$.

The teacher's task therefore, is to spark engagement by striking a personal chord, making contact with students and, if necessary, reaching out into a space where students are at ease. This has the potential to work well through a combination of face-to-face and virtual contact. The teacher can get to know students through face-to-face activities in a genuinely student-friendly learning space. The skills audit and workshops organised at the start of 'Management at Work' helped to achieve this. Later activity took place in a classroom designed for informal groups, some with a networked computer for workshop activity and others sitting in armchairs around a coffee table. This arrangement allows the teacher to reach out to students in small groups rather than expecting students who lack confidence to respond in the whole class forum. Online activities can then be designed to engage the students' personal interests and emotions. The original topic for the first discussion in 'Management at Work' (sharing experiences of management) was therefore replaced with a subject-related topic triggering personal feelings.

You have chosen to study heritage, environmental or community management. Tell your group about something that excites or angers you connected with your subject.

\section{In summary}

Participation in online discussion has many benefits, not least potential to develop skills and confidence in a learning community, so by failing to participate effectively, students miss an opportunity for personal growth. There are many barriers to participation but the case study shows that, once technical skills and access to the online environment have been addressed, motivation for joining in remains a tough nut to crack, while forcing participation through assessment is not enough. The problem preventing students from timely participation in discussions lay in a lack of motivation generated by a poorly-designed activity on a subject that was not immediately attractive to them despite the extrinsic motivation of assessment. An activity originally designed to draw out each individual student's experiences of management proved uninspiring and failed to counter preconceptions about management as a dull subject. Instead, students argued for an opportunity to discuss their interest, in some cases a real passion, in their subject.

A teacher might know in theory that it is important to recognise students' individual needs, but can easily miss putting this into practice. Teachers need to focus on the importance of reaching out to individuals, making personal contact and touching each person's emotional interest. If online discussion is to be successful as a tool for building a strong sense of community, it must motivate each individual student to engage 
from the outset. The test is "to design a first discussion topic that is so enticing, so intriguing, and so marvellous that they really do not want to miss out on it" (Bender 2003, 47).

\section{References}

Barnett, R., and K. Coate. 2004. Engaging the curriculum in higher education. Maidenhead, UK: Open University Press.

Beetham, H., and R. Sharpe. 2007. Rethinking pedagogy for a digital age. London: Routledge.

Bender, T. 2003. Discussion-based online teaching to enhance student learning. Sterling, VA: Stylus Publishing.

Bourne, J.R., E. McMaster, J. Reiger, and J.O. Campbell. 1997. Paradigms for on-line learning: A case study in the design and implementation of an asynchronous learning networks (ALN) course. Journal of Asynchronous Learning Networks 1, no. 2: 38-56.

Coates, H. 2006. Student engagement in campus-based and online education. Abingdon, UK: Routledge.

Dalziel, D., E. Hewitt, and L. Evans. 2007. Motivations and barriers to citizen governance. London: Communities and Local Government.

Deci, E.L., and R.M. Ryan. 1985. Intrinsic motivation and self-determination in human behaviour. New York: Plenum Press.

Downing, K.J., T. Lam, T. Kwong, W. Downing, and S. Chan. 2007. Creating interaction in online learning: A case study. ALT-J Research in Learning Technology 15, no. 3: 201-15.

Ellis, R.A., P. Goodyear, A. O'Hara, and M. Prosser. 2007. The university student experience of face-to-face and online discussions: Coherence, reflection and meaning. ALT-J Research in Learning Technology 15, no. 1: 83-97.

Entwistle, N. 2003. Occasional report 3: Concepts and conceptual frameworks underpinning the ETL Project. Edinburgh: ETL Project.

Ferreday, D., and V. Hodgson. 2008 The tyranny of participation and collaboration in networked learning. Paper presented at the $6^{\text {th }}$ International Conference Networked Learning, May 5-6, in Halkidiki, Greece. http://www.networkedlearningconference.org.uk/past/ nlc2008/abstracts/PDFs/Hodgson_640-647.pdf

Fraser, H. 2005. Four different approaches to community participation. Community Development Journal 40, no. 3: 286-300.

Garrison, D.R., and T. Anderson. 2003. E-learning in the 21st century. London: Routledge Falmer.

Gilchrist, A. 2004. Community cohesion and community development: Bridges or barricades. London: Community Development Foundation.

Henderson, P., and D.N. Thomas. 2002. Skills in neighbourhood work. 3rd ed. London: Routledge.

Krause, K. 2007. Accommodating diverse approaches to student engagement. Paper presented at a seminar, April 16, at the University of Gloucestershire, Cheltenham. http://resources.glos.ac.uk/shareddata/dms/57C1B3F7BCD42A0398208AFD6C7CAB72. pdf

MacDonald, J. 2006. Blended learning and online tutoring: A good practice guide. Aldershot, UK: Gower.

MacDonald, J., W. Atkin, F. Daugherity, H. Fox, A. MacGillivray, D. Reeves-Lipscomb, and P. Uthailertaroon. 2003. Let's get more positive about the term 'lurker'. CPsquare Foundations of Communities of Practice Workshop. http://www.cpsquare.org/edu/News/ archives/LurkerProjectCoPWorkshopSPring03a.doc

Moseley, M. 2003. Rural development: Principles and practice. London: Sage.

Moule, P. 2007. Challenging the five-stage model for e-learning: A new approach. ALT-J Research in Learning Technology 15, no. 1: 37-50.

Oliver, R., B. Harper, S. Wills, S. Agosthino, and J. Hedberg. 2007. Designing and delivering e-learning. In Rethinking pedagogy for a digital age, ed. H. Beetham and R. Sharpe, 64-80. London: Routledge.

Salmon, G. 2000. E-moderating: The key to teaching and learning online. London: Kogan Page. 
Salmon, G. 2007. The tipping point. ALT-J Research in Learning Technology 15, no. 2: $171-2$.

Skidmore, P., K. Bound, and H. Lownsborough. 2006. Community participation: Who benefits? York, UK: Joseph Rowntree Foundation.

Skinner, E. 2007. Building knowledge and community through online discussion. Journal of Geography in Higher Education 31, no. 3: 381-91.

Skinner, E., and J. Derounian. 2008. Building community through online discussion. Learning and Teaching in Higher Education, no. 2: 58-71

Warburton, D. 1998. Community and sustainable development. London: Earthscan.

Wenger, E. 1998. Communities of practice: Learning, meaning, and identity. Cambridge, UK: Cambridge University Press. 